\title{
O WYRAŻANIU RADOŚCI (NA PRZYKŁADZIE ROSYJSKICH KONSTRUKCJI Z PREDYKATEM РАД I ICH POLSKICH ODPOWIEDNIKÓW PRZEKŁADOWYCH)
}

\author{
ON EXPRESSING JOY (BASED ON THE EXAMPLE OF RUSSIAN \\ STRUCTURES WITH PREDICATE РАД AND THEIR POLISH TEXT \\ EQUIVALENTS)
}

СОФИЯ ЧАПИГА

\begin{abstract}
The author concentrates on the typically Russian structures with predicate pad, which expresses joy, and their Polish equivalents. It turns out that, apart from dictionary counterparts (rad, cieszyć się), also other lexemes with similar meaning (zadowolony, mito, przyjemnie) appear. As a result, sentences containing such structures are semantically similar, even if they differ syntactically. The use of some forms (e.g.: pad / mito mi) is, in some situations, a sign of obeying certain social norms of behavior.
\end{abstract}

Zofia Czapiga, Uniwersytet Rzeszowski, Polska - Polska.

Radość to rodzaj przyjemnego uczucia będącego zwykle wynikiem pomyślnego zbiegu zdarzeń w życiu człowieka. To właśnie radość sprawia, że człowiek jest $\mathrm{w}$ dobrym nastroju i ma siłę do podejmowania różnych wyzwań, czy też jest gotów zmierzyć się z zadaniami i trudnościami, które napotyka w życiu codziennym. „Gdy przyjemne stany uczuciowe nabierają w pewnych warunkach szczególnej intensywności - pisze W. Tatarkiewicz - [...] nie mówimy o przyjemności, ale o radości lub zadowoleniu. Swą zwiększoną intensywność osiągają one na dwu podłożach: organicznym i umysłowym"1. Radość odnosi on do przyjemnych afektów, kiedy podniecenie organizmu wzmaga nie przykrość, lecz przyjemność. „I przezeń przyjemność uzyskuje tak wielką siłę, jaka tylko w afekcie jest możliwa. Afekt tego rodzaju nazywamy radością"2. A. Wierzbicka eksplikuje ten stan psychiczny następująco:

Radość = uczucie, którego doznajemy wtedy, kiedy stwierdzamy, że dzieje się to, co pragniemy, aby się działo ${ }^{3}$.

${ }^{1} \mathrm{~W}$. T a t a r k i e w i c z, O szczęściu, Warszawa 2004, s. 79.

2 Tamże, s. 80. Zob. także: Е.П. И л ь и ч, Эмоциии и чувства, Москва 2007, s. 178; В.И. Ш а х о в с к и й, Лингвистическая теория эмоций, Москва 2008, s. 14.

${ }^{3}$ A. W i e r z b i c k a, Kocha, lubi, szanuje. Medytacje semantyczne, Warszawa 1971, s. 62. 
I. Nowakowska-Kempna w grupie radości wyróżnia takie leksemy jak cieszyć się, weselić się, radość, (czuć się) lekko, bezpiecznie, beztrosko, rad, kontent, uciech $a^{4}$. Rosyjski szereg synonimiczny przy dominancie радоваться tworzą рад, радовать, испытывать радость, миковать, торжествовать; возвеселяться (CC).

W języku rosyjskim typową formą wyrażania uczucia radości jest krótka forma przymiotnika pad używana w funkcji predykatywnej (b зн. сказ. кому-, чему-л. 'О чувстве радости, удовольствия, испытываемом кем-л.' СРЯ). Polskim odpowiednikiem słownikowym jest słowo przestarzałe, dziś książkowe rad ('Jeśli ktoś jest rad z jakiejś sytuacji, rzeczy lub osoby, to jest z niej zadowolony' ISJP) oraz neutralny stylistycznie czasownik cieszyć sie ('Doznawać radości, zadowolenia; radować się, weselić się' SDor). Emocjonalność jest charakterystyczną cechą języka mówionego ${ }^{5}$, stąd predykat pad jest szeroko używany w dialogu jako:

1) forma powitań, zwykle w pozycji inicjalnej, odzwierciedlająca zadowolenie z zaistniałego stanu rzeczy - spotkania z bliską lub znajomą osobą, np.:

[1] Маргарита выпустила ухо, и назойливые, мрачные глаза оказались перед ней.

- Я счастлива, королева-хозяйка, быть приглашенной на великий бал полнолуния.

- А я, - ответила ей Маргарита, - рада вас видеть. Очень рада.

Natarczywe, posępne oczy znalazły się przed Małgorzatą.

- Jestem szczęśliwa, królowo i pani, że zostałam zaproszona na wielki bal pełni księżyca!

- A ja cieszę się, że panią widzę - odpowiedziała jej Małgorzata. - Bardzo się cieszę (Bułhakow).

[2] - Здравствуйте. Здравствуйте. Очень приятно. Отчасти предуведомлен. Самдевятов Анфим Ефимович с разъезда Сакмы по дорожному телефону навертел. Доктор Живаго с семьей из Москвы, прошу, говорит, окажите всемерное содействие. Этот самый доктор, стало быть, вы и будете?

- Нет, доктор Живаго это он вот, мой зять, а я по другой части, по сельскому хозяйству, профессор агроном Громеко.

- Виноват, обознался. Извините. Очень рад познакомиться.

- Przepraszam, pomyliłem się. Przepraszam. Bardzo mi miło poznać państwa (Pasternak) ${ }^{6}$.

${ }^{4}$ I. N o w a k o w s k a - K e m p n a, Konstrukcje zdaniowe z leksykalnymi wykładnikami predykatów uczuć, Katowice 1986, s. 54, 137.

${ }^{5}$ В.И. Ш а х о в с к и й, Категоризация эмоциии в лексико-семантической системе языка, Москва 2008, s. 146.

${ }^{6}$ Ze względów ekonomicznych polskie fragmenty niekiedy przytaczane są w nieco skróconej wersji, ograniczonej do zdań zawierających dany leksem, z pominięciem szerszego kontekstu obecnego w przykładzie rosyjskim. 
Nierzadko są to skonwencjonalizowane użycia grzecznościowe mające ułatwić i uprzyjemnić kontakt między uczestnikami dialogu. Nie zawsze są faktycznym odzwierciedleniem stanu psychicznego radości, a jedynie wynikają z normy obyczajowej, że w danej sytuacji inaczej zachować się nie wypada.

2) reakcja na miłe zachowanie słowne współrozmówcy, np.:

[3] - Как я счастлива, черная королева, что мне выпала высокая честь, - монашески шептала Тофана, пытаясь опуститься на колено. Испанский сапог мешал ей. Коровьев и Бегемот помогли Тофане подняться.

- Я рада, - ответила ей Маргарита, в то же время подавая руку другим.

- Jakże jestem szczęśliwa, o szlachetna królowo, że spotkał mnie ten wielki zaszczyt... - szeptała Tofana, jak to czynią mniszki, usiłując jednocześnie przyklęknąć, w czym przeszkadzał jej but hiszpański. Korowiow i Behemot pomogli signorze podnieść się.

- Bardzo mi miło - odpowiedziała jej Małgorzata jednocześnie podając dłoń innym (Bułhakow).

3) w obszerniejszej wypowiedzi jest wyrazem zadowolenia, radości z zaistniałego w danej chwili czy wcześniej stanu rzeczy, np.:

[4] - Ну вот, все и кончилось, - говорил арестованный, благожелательно поглядывая на Пилата, - и я чрезвычайно этому рад.

- Oto wszystko się już skończyło - życzliwie spoglądając na Piłata, mówił aresztowany - i niezmiernie się $\mathbf{z}$ tego cieszę (Bułhakow).

W dialogu interlokutorzy nazywają swoje emocje równoczesne z momentem mówienia, stąd zdecydowanie dominuje czas teraźniejszy, pierwsza osoba l. poj. (rzadziej l. mn.). W języku rosyjskim subiekt wskazywany jest zwykle zaimkiem osobowym, natomiast dla języka polskiego typowe jest użycie pierwszoosobowej formy czasownikowej ciesze się, oznaczającej pozytywne uczucie radości, przyjemności i zadowolenia. Sporadycznie interlokutor odnosi swój stan psychiczny do przeszłości czy przyszłości. Niewątpliwie wynika to $\mathrm{z}$ faktu, że w obu kręgach językowo-kulturowych w sytuacji komunikacji międzyludzkiej - w dialogu - używa się ściśle określonych przez konwencję obyczajową form etykiety grzecznościowej ${ }^{7}$, w tym przypadku form opartych na leksemach pad i cieszyć się.

Poza dialogiem omawiany predykat pojawia się rzadko jako informacja o stanie zadowolenia innych niż nadawca osób lub jego samego, np.:

${ }^{7}$ M. M a r c j a n i k, O radości nie z serca, lecz z konwencji (grzecznościowej), [w:] Anatomia szczęścia. Emocje pozytywne w językach i kulturach świata, pod red. A. Duszak i N. Pawlak, Warszawa 2005, s. 203. 
[5] Доктор вспомнил, что ему предстоит объяснение с Антиповой, как бы то ни было, неприятное. Он был рад необходимости ее увидеть, пусть и такой ценой. Но едва ли она уже приехала.

Doktor przypomniał sobie, że czeka go rozmowa z Antipową, i to rozmowa raczej nieprzyjemna. Cieszył się jednak, że ją zobaczy, choćby nawet za taką cenę. Przy pierwszej sposobności wstał i dyskretnie wyszedł z gabinetu (Pasternak).

[6] С вечера Иннокентий был рад всякому мелкому событию, всякому открыванию двери, нарушающему его одиночество, его непривычное сидение в западне. Сейчас наоборот - хотелось додумать некую важную, еще не уловленную им мысль - и он рад был, что его отвели в прежний бокс и долго не беспокоили, хотя непрестанно подсматривали в глазок. Jeszcze wieczorem Innocenty był rad każdemu drobnemu wydarzeniu, każdemu otwarciu drzwi przerywającemu to samotne siedzenie w pułapce. Teraz natomiast miał chęć przemyślenia do końca czegoś, co niezupełnie jeszcze rozumiał - i był zadowolony, że zaprowadzono go do dawnego boksu i że długo mu nie przeszkadzano, chociaż wciąż zaglądano przez judasza (Sołżenicyn).

Kauzatorem radości zawsze są czynniki przyjemne, pozytywne. W słowniku składniowym G. Zołotowej kauzator jest definiowany jako „компонент со значением воздействующего фактора (предмета или явления)" ${ }^{\prime \prime}$. W języku rosyjskim kauzator orzekanego stanu komfortu psychicznego ma zróżnicowane wykładniki formalne. Są to:

- celownikowa forma imienna, np.:

[7] Потом Саша отправился к Лозгачеву. Тот улыбнулся так, будто рад его успеху.

Następnie Sasza udał się do Łozgaczewa. Łozgaczew na widok Saszy rozpromienił się, jak gdyby pozytywny finał sprawy cieszył go osobiście (Rybakow).

[8] - Почту разбираете?

- Да, много пришло. У вас, наверное, тоже?

- И что нового? - ответил Всеволод Сергеевич вопросом.

- Особенного ничего... Письма от матери, от друзей. Я им рад.

- Nic specjalnego... Listy od matki, od przyjaciół. Bardzo się z nich cieszę (Rybakow).

Kauzator celownikowy najczęściej nazywa zaistniały stan rzeczy, sytuację sprawiającą radość (pozytywne rozwiązanie sprawy Saszy), rzadziej konkretne przedmioty, desygnaty, które w zasadzie również odnoszą się do pewnych zdarzeń (listy - tj. to, że przychodzą listy od matki, przyjaciół; że

8 Г.А. 3 о л о т о в а, Синтаксический словарь. Репертуар элементарных единии русского синтаксиса, Москва 1988, с. 431. 
oni piszą do niego). W przypadku użycia zaimków ma miejsce anaforyczne odesłanie do kauzatora nazwanego w poprzednim zdaniu.

- forma biernikowa z przyimkiem зa, np.:

[9] Праздника не получилось. Его исключение взбудоражило всех, восстановление - никого. Только Криворучко, подписывая новый Сашин студенческий билет, сказал:

- Рад за тебя.

- Cieszę się (Rybakow).

[10] Марк Александрович был рад за сестру и за себя: посещение будет не таким тяжким, как он опасался.

Marek Aleksandrowicz cieszył się ze względu na siostrę i na siebie: wizyta nie będzie tak trudna, jak się spodziewał (Rybakow).

Formą зa N (Pron)a bywa nazywany kauzator osobowy (рад за сестрy, за первых встречных, за тебя), ale i tu forma imienna sygnalizuje określony stan rzeczy: Kriworuczko cieszył się, że Saszę ponownie przyjęto do instytutu; praca wzmocniła siostrę, dodała sił i wytrzymałości i Markowi łatwiej będzie rozmawiać o aresztowaniu Saszy. W pierwszym przykładzie [9] w polskiej wersji kauzator został pominięty, ale można się go domyślić $\mathrm{z}$ kontekstu, natomiast $\mathrm{w}$ drugim [10] - pojawia się inna forma gramatyczna.

- bezokolicznik, np.:

[11] Яконов и Сологдин почти не разговаривали раньше: вызывать Сологдина в этот кабинет надобностей не было, в конструкторском же бюро и при встречах в коридоре инженер-полковник не замечал личности, столь незначительной. Но сейчас (скосясь на список имен-отчеств под стеклом) со всем радушием хлебосольного барина Яконов одобрительно посмотрел на вошедшего и широко пригласил:

- Садитесь, Дмитрий Александрович, очень рад вас видеть.

- A, Dymitr Aleksandrowicz? Bardzo rad jestem pana widzieć (Sołżenicyn).

[12] Бунчук за руку поздоровался с остальными казаками, ответил надломленным, чугунно-глухим голосом:

- Приехал из Питера, насилу разыскал вас. Дело есть. Надо потолковать.

Я, брат, рад видеть тебя живым и здоровым.

- Przyjechałem z Pitra. Ledwo was odszukałem. Mam interes. Musimy pogadać. Cieszę się, że widzę cię zdrowego i całego (Szołochow).

Kauzatorem orzekanej radości jest nazwana w bezokoliczniku konkretna czynność: рад видеть, услышать, встретить, познакомиться. Zdania mają monosubiektowy, polipredykatywny ${ }^{9}$ charakter: Я вас Вижу. + Я рад

${ }^{9}$ O polipredykatywności zob. Z. C z a p i g a, Polipredykatywność zdania pojedynczego w języku polskim i rosyjskim, Rzeszów 1994. 
этому. Potwierdzeniem polipredykatywności zdania jest przekład ostatniego przykładu, w którym bezokolicznik został zamieniony w języku polskim osobową formą czasownika organizującą pełną strukturę predykatowo-argumentową.

- zdanie składnikowe zdania złożonego ze spójnikiem umo, np.:

[13] Зря она сказала, что никто не знает сейчас „мирискусников”. Михаил Юрьевич огорчился.

- Михаил Юрьевич, я готова сидеть у вас часами, вы не устаете от меня?

- Что вы, Варя, нисколько! Я рад, что вы приходите.

- Co też, Wariu, ani trochę! Zawsze się cieszę, kiedy pani przychodzi (Rybakow).

[14] Филипп Филиппович, стукнув, снял трубку с телефона и сказал в нее так:

- Пожалуйста... Да... Благодарю вас. Петра Александровича попросите, пожалуйста. Профессор Преображенский. Петр Александрович? Очень рад, что вас застал. Благодарю вас, здоров.

- Proszę... tak... dziękuję. Poproszę Piotra Aleksandrowicza. Mówi profesor Preobrażeński. Piotr Aleksandrowicz? Cieszę się, że pana zastałem. Dziękuję, z moim zdrowiem wszystko w porządku (Bułhakow).

Sytuacja wywołująca uczucie radości subiektu jest tu nazywana pełną jednostką predykatywną, podrzędną w stosunku do zdania z predykatem рад / ciesze się (что вы приходите; Анете лучше; она не заходит; она смеется; застал вас; защищаешь Марину; отбросил его itр.).

Kauzator radości nie zawsze jednak jest wskazywany na powierzchni i wtedy można go określić na podstawie szerszego kontekstu, np.:

[15] И в этот самый момент в оконце послышался носовой голос:

- Мир вам.

Мастер вздрогнул, а привыкшая уже к необыкновенному Маргарита вскричала:

- Да это Азазелло! Ах, как это мило, как это хорошо! - и, шепнув мастеру:

- Вот видишь, видишь, нас не оставляют! - бросилась открывать.

- Ты хоть запахнись, - крикнул ей вслед мастер.

- Плевала я на это, - ответила Маргарита уже из коридорчика.

И вот уже Азазелло раскланивался, здоровался с мастером, сверкал ему своим кривым глазом, а Маргарита восклицала:

- Ах, как я рада! Я никогда не была так рада в жизни!

I oto Azazello już się kłaniał, już się witał z mistrzem, pobłyskując swoim białym okiem, Małgorzata zaś wołała:

- Ach, jak się cieszę! Nigdy w życiu tak się nie cieszyłam! (Bułhakow).

Małgorzacie ogromną radość sprawiło przybycie niezapowiedzianego gościa - Azazella, świadczące o tym, że nie zapomniano ani o niej, ani o mistrzu. 
Rosyjskie zdania z leksemem pad mają w polskich tekstach zróżnicowane odpowiedniki przekładowe, co nierzadko pociąga za sobą rozbieżności formalno-składniowe, przy zachowaniu jednak w większości przypadków zawartości semantycznej wypowiedzenia. Są to:

1) zdania z ekwiwalentami słownikowymi

[16] Юра был рад, что дядя взял его в Дуплянку. Там было очень красиво, и живописность места тоже напоминала маму, которая любила природу и часто брала Юру с собой на прогулки. Кроме того, Юре было приятно, что он опять встретится с Никой Дудоровым, гимназистом, жившим у Воскобойникова, который, наверное, презирал его, потому что был года на два старше его, и который, здороваясь, с силой дергал руку книзу и так низко наклонял голову, что волосы падали ему на лоб, закрывая лицо до половины.

Jura był rad, że wuj zabrał go do Dublanki (Pasternak).

[17] - Я очень рада, что Анете лучше. Мы с Пьером так за нее беспокоились.

- Bardzo się cieszę, że Aneta lepiej się czuje. Oboje z Pierrem bardzo się o nią martwiliśmy (Pasternak).

[18] - Я рад, Гордон, что ты защищаешь Марину, как прежде был всегда Тониным защитником. Но ведь у меня нет с ними разлада, я не веду войны ни с ними, ни с кем бы то ни было. Ты меня упрекал вначале, что она говорит мне вы в ответ на мое ты, и величает меня по имени-отчеству, точно и меня это не угнетало.

- Cieszę się, Gordon, że bronisz Mariny, tak jak zawsze przedtem ujmowałeś się za Tonią (Pasternak).

Przestarzały, dziś książkowy leksem rad jest używany w języku polskim zdecydowanie rzadziej niż neutralny stylistycznie czasownik cieszyć się, co potwierdza również badany materiał.

2) przymiotnik zadowolony (a)

[19] - Ах, оставьте, - возражал Юрий Андреевич. - Посмотрите на эти станции. Деревья не спилены. Заборы целы. А эти рынки! Эти бабы! Подумайте, какое удовлетворение! Где-то есть жизнь. Кто-то рад. Не все стонут. Этим все оправдано.

- Ależ co pan - oponował Jurij Andriejewicz. - Niech pan popatrzy na te stacje. Drzewa nieścięte. A te stragany! Te baby! Aż miło spojrzeć. A więc gdzieś jest życie. Ktoś jest zadowolony. Nie wszyscy narzekają. I to usprawiedliwia inne zjawiska (Pasternak).

[20] Замужество Вари Софья Александровна перенесла стоически: что делать, еще одна живая душа отходит от Саши. Все его друзья забыли о нем, 
не звонят, не интересуются, ни Вадим, ни Лена Будягина, о Юре Шароке и говорить нечего - он с ней даже не здоровается. Нина Иванова первое время заходила, а теперь не заходит, бойкотирует Софью Александровну, давшую приют Варе и Косте. Откровенно говоря, Софья Александровна была даже рада, что она не заходит.

Szczerze mówiąc, Sofia Aleksandrowna była nawet zadowolona, że Nina nie przychodzi (Rybakow).

Semantycznie zdania te się nie różnią - przymiotnik zadowolony i rad są bliskoznaczne.

3) przysłówek miło

[21] - Да, - говорила горничная в телефон, - как? Барон Майгель? Слушаю. Да! Господин артист сегодня дома. Да, будет рад вас видеть.

- Tak - mówiła do słuchawki pokojówka. - Kto? Baron Meigel? Słucham pana. Tak. Pan artysta będzie dziś w domu. Tak, będzie mu bardzo miło powitać pana (Bułhakow).

[22] - Граф Роберт, - шепнул Маргарите Коровьев, - по-прежнему интересен. Обратите внимание, как смешно, королева - обратный случай: этот был любовником королевы и отравил свою жену.

- Мы рады, граф! - вскричал Бегемот.

- Hrabia Robert - szepnął Małgorzacie Korowiow - także ciekawa postać. Proszę zwrócić uwagę, królowo, jak zabawnie się składa - to odwrotny przypadek. Hrabia Robert był kochankiem królowej i otruł swoją żoną.

- Bardzo nam miło, hrabio! - wykrzyczał Behemot (Bułhakow).

Przysłówek mito jest tu używany w konwencjonalnych zwrotach grzecznościowych, sygnalizując zadowolenie ze spotkania danej osoby, witania się z nią itp.

\section{4) przysłówek przyjemnie}

[23] Закрутилась машина, искали документы, готовили справки. Лозгачев, уже назначенный вместо Янсона деканом, быстро и даже предупредительно оформил Сашину зачетную книжку, его гладкое лицо как бы говорило: лично я против тебя ничего не имею, так сложились обстоятельства, ну, если тебя восстановят, буду искренне рад.

Machina poszła w ruch, wyszukiwano dokumenty, przygotowywano zaświadczenia. Łozgaczew, mianowany już dziekanem na miejsce Jansona, szybko i uprzedzająco grzecznie wydał Saszy indeks, jego gładka twarz zdawała się mówić: osobiście nic przeciwko tobie nie mam, tak się złożyły okoliczności, jeżeli przyjmą cię z powrotem, będzie mi bardzo przyjemnie (Rybakow).

Przysłówek przyjemnie, zwłaszcza w połączeniu z intensyfikatorem bar$d z o$, również odzwierciedla stan komfortu psychicznego - stan zadowo- 
lenia z zaistniałej sytuacji, jednak jest ono mniej intensywne niż radość sygnalizowana $\mathrm{w}$ tekście oryginału.

\section{5) jestem szczęśliwa}

[24] Зида чувствовала его отчуждение, его охладение, как-то сказала:

- Не думай, что я хочу тебя женить на себе. У тебя, наверно, кто-то есть в Москве, а я так, от тоски, от скуки. И все равно я рада своему счастью.

- Nie myśl, że chcę się za ciebie wydać za mąż. Pewnie masz kogoś w Moskwie, a mnie tylko tak, z tęsknoty, z nudów. I mimo to jestem szczęśliwa (Rybakow).

Struktura semantyczna polskiego wypowiedzenia została uszczuplona o komponent nazywający stan radości Ziny, wynikający z faktu, że jest szczęśliwa. Rosyjskie zdanie ma bardziej rozbudowaną strukturę - jest polipredykatywne: Я счастлива. + Я рада тому.

Dla podkreślenia czy też wzmocnienia siły, skali przeżywanego uczucia często wykorzystywane są intensyfikatory typu очень, весьма, несказанно, безумно, безмерно, бесконечно, необыкновенно, чрезмерно, чрезвычайно, страшно, ужасно; bardzo, ogromnie, niesamowicie, niezmiernie, szalenie, bądź powtórzenia formuł (reduplikacja), nierzadko w kontekście innych wykładników pozytywnych emocji, np.

[25] Она смеялась словно с неохотой, нагнув голову и отвернувшись, подетски вытирая слезы ладошкой, и Скворцов рад был, что она смеется, ужасно рад! [k] $]^{10}$.

[26] - Очень приятно было снова с вами встретиться. Очень рад. Очень рад [k].

Centralne leksemy pad//cieszyć się niewystarczająco odzwierciedlają ekspresję emocji, dlatego mówiący sięga po dodatkowe środki wyrażania intensywności swych uczuć. Niektóre z nich (ужасно, страшно, strasznie, szalenie) prymarnie służą do podkreślenia natężenia lub rozmiaru jakichś zjawisk, zwłaszcza negatywnych, jednak potocznie używane są też w znaczeniu 'bardzo, niezmiernie, nadzwyczaj; ogromnie' (SPopr) w odniesieniu również do zjawisk czy stanów pozytywnych. Interesująco wygląda kwestia intensyfikatorów w badanym materiale. Otóż okazuje się, że w przekładzie na język polski obok ekwiwalentów słownikowych (очень - bardzo, чрезbычайно - niezmiernie, как - jak) wykorzystywane są inne, o podobnym znaczeniu leksemy (очень - szalenie, страшно - szalenie, искренне - bardzo). literą [k].

10 Oprócz tekstów literackich źródłem materiału były korpusy, co zostało oznaczone 
Z kolei bywa i tak, że tłumacz w jednostkowych przypadkach pomija intensyfikator lub, co zdarza się częściej, dodaje go. Por.:

[27] Филипп Филиппович, стукнув, снял трубку с телефона и сказал в нее так:

- Пожалуйста... Да... Благодарю вас. Петра Александровича попросите, пожалуйста. Профессор Преображенский. Петр Александрович? Очень рад, что вас застал. Благодарю вас, здоров.

- Proszę... tak... dziękuję. Poproszę Piotra Aleksandrowicza. Mówi profesor Preobrażeński. Piotr Aleksandrowicz? Cieszę się, że pana zastałem. Dziękuję, z moim zdrowiem wszystko w porządku (Bułhakow).

[28] - Да, - говорила горничная в телефон, - как? Барон Майгель? Слушаю. Да! Господин артист сегодня дома. Да, будет рад вас видеть.

- Tak - mówiła do słuchawki pokojówka. - Kto? Baron Meigel? Słucham pana.

Tak. Pan artysta będzie dziś $\mathrm{w}$ domu. Tak, będzie mu bardzo miło powitać pana (Bułhakow).

Dodawanie przez tłumacza ${ }^{11}$ dodatkowych intensyfikatorów potwierdza tezę, że w języku polskim sam wykładnik stanu oznacza niewielką skalę emocji i że istnieje zgoda kulturowa na przekazywanie innym, że jest się pod wpływem silnego przeżycia12, bądź też że w danej sytuacji należy zareagować tak, nie inaczej. Dotyczy to głównie czasownika cieszę się i przysłówka mito.

Przytoczony materiał potwierdza wyjątkowość typowych dla języka rosyjskiego konstrukcji z leksemem pad, o czym świadczy m.in. zróżnicowane tłumaczenie na język polski, z pewnymi przekształceniami strukturalnymi, niekiedy $\mathrm{z}$ ewidentnym pomijaniem niektórych istotnych elementów wypowiedzi, co w efekcie odbija się również na adekwatności semantycznej. W większości jednak przypadków używane są ekwiwalenty słownikowe lub leksemy o zbliżonym znaczeniu typu zadowolony, mito, przyjemnie, odzwierciedlające stan zadowolenia, radości z zaistniałej sytuacji. Ekspresja tego uczucia bywa wzmacniana przez szerokie użycie intensyfikatorów, zwłaszcza w odniesieniu do zdarzeń aktualnych, równoczesnych z momentem mówienia. Świadczy to o potrzebie wyrażania uczuć na zewnątrz oraz ujawniania ich intensywności, siły. Używanie niektórych form (np. pad/miło mi) w pewnych sytuacjach jest jednak tylko wyrazem przestrzegania uwarunkowanych kulturowo norm etykiety grzecznościowej.

${ }^{11}$ Dodawanie intensyfikatora ma miejsce głównie w tłumaczeniu powieści M. Bułhakowa Mistrz i Małgorzata w wykonaniu I. Lewandowskiej i W. Dąbrowskiego.

12 Zob. A. M i k o ł a j c z u k, O wyrażaniu i komunikowaniu uczuć w języku polskim (na przykładzie radości), [w:] Wyrażanie emocji, pod red. K. Michalewskiego, Łódź 2006, s. $88-89$. 
Wykaz symboli i skrótów

\begin{tabular}{|c|c|c|}
\hline $\mathrm{a}$ & - & biernik \\
\hline $\mathrm{N}$ & - & rzeczownik \\
\hline Pron & - & zaimek \\
\hline ISJP & - & $\begin{array}{l}\text { Inny stownik języka polskiego, M. Bańko (red.), t. 1-2, War- } \\
\text { szawa } 2000 .\end{array}$ \\
\hline SDor & - & $\begin{array}{l}\text { Słownik jezzyka polskiego, W. Doroszewski (red.), t. 1, } \\
\text { Warszawa 1958. }\end{array}$ \\
\hline SPopr & - & $\begin{array}{l}\text { Stownik poprawnej polszczyzny PWN, W. Doroszewski (red.), } \\
\text { Warszawa } 1980 .\end{array}$ \\
\hline СРЯ & - & $\begin{array}{l}\text { Словарь русского языка: } \text { в четырех томах, А.П. Евгеньева } \\
\text { (ред.), т. 1-4, Москва 1981-1984. }\end{array}$ \\
\hline $\mathrm{CC}$ & - & $\begin{array}{l}\text { 3.Е. Александрова, Словарь синонимов русского языка, } \\
\text { Москва } 1975 .\end{array}$ \\
\hline
\end{tabular}


